\title{
Analysis of maternal and perinatal outcomes in cases with twin-to-twin transfusion syndrome (TTTS)
}

\author{
Serdar Başaranoğlu', Senem Yaman Tunç², Abdulkadir Turgut², Elif Ağaçayak², Nurullah Peker², \\ Mehmet Sait İçen², Ahmet Yalınkaya² \\ 'Obstetrics \& Gynecology Clinic, İdil State Hospital, Şırnak, Turkey \\ ${ }^{2}$ Department of Obstetrics \& Gynecology, Faculty of Medicine, Dicle Universtiy, Diyarbakur, Turkey
}

\begin{abstract}
Objective: Our aim was to analyze maternal and perinatal outcomes of the pregnant women with twin-to-twin transfusion syndrome (TTTS) having a complex physiopathology and developed in monochorionic diamniotic pregnant.

Methods: In this study, 330 multiple pregnancies who gave birth at our university clinic between July 2008 and December 2013 were reviewed retrospectively. The demographic data, obstetric history, gestational weeks by ultrasonography, chorionicity and amnionicity conditions, treatment and delivery methods and newborn information were obtained from archive records and electronic database of the hospital. TTTS syndrome staging was carried out according to the criteria reported by Quintero et al. (1999).

Results: It was found that 13,368 deliveries were carried out in our clinic and 307 of them were twin pregnancies during the period stated. While $196(63.8 \%)$ of the twin pregnancies were dichorionic diamniotic, $99(32.2 \%)$ of them were monochorionic diamniotic and $12(3.9 \%)$ of them were monochorionic monoamniotic. Spontaneous pregnancy was observed in $256(83.4 \%)$ women and pregnancy after assisted reproduction techniques was observed in 51 (16.6\%) women. Thirty-one $(31.3 \%)$ of monochorionic diamniotic pregnancies were complicated with TTTS. When classifying the newborns, receiver fetuses (fetuses with polyhydramnios) were grouped as Fetus-A and donor ones (fetuses with oligohydramnios or those in stuck-twin appearance) were grouped as Fetus-B. The weight of postpartum newborns was $2089 \pm 639 \mathrm{~g}$ in Fetus-A group, and $1262 \pm 489 \mathrm{~g}$ in Fetus-B group $(\mathrm{p}<0.001)$.

Conclusion: Chorionicity and amnionicity determination of monochorionic twin pregnancies should be done at early weeks and patients should be called for their antenatal follow-ups more frequently. During their antenatal follow-ups, they should be recommended to refer to the centers having the experience to manage complications which may develop in case of fetal development differences, amniotic fluid inconsistencies or doubt in their Doppler profiles. The importance of staging in patients developing twin-totwin transfusion syndrome should be acknowledged and it should be remembered that pleasing results are achieved after the treatment in newborns with early stage (stage I-II) TTTS.
\end{abstract}

Keywords: Multiple pregnancy, twin pregnancy, transfusion, maternal and fetal outcomes.
Özet: İkizden ikize transfüzyon sendromu (TTTS) olgularında maternal ve perinatal sonuçların değerlendirilmesi

Amaç: Monokoryonik diamniyotik gebelerde gelișen ve karmaşık bir fizyopatolojiye sahip ikizden ikize transfüzyon sendromlu (TTTS) gebelerin maternal ve perinatal sonuçlarının değerlendirilmesi amaçland.

Yöntem: Bu çalışmada Dicle Üniversitesi Kadın Hastalıkları ve Doğum Kliniğinde Temmuz 2008 ile Aralık 2013 tarihleri arasında doğumu gerçekleșen 330 çoğul gebelik geriye yönelik olarak incelendi. Olgulara ait demografik veriler, obstetrik öykü, ultrasonografik ile gestasyonel haftalar, koryonisite ve amniyonisite durumları, tedavi ve doğum șekilleri ile yenidoğan bilgileri hastane arşiv kayıtlarından ve elektronik veri tabanından elde edildi. Quintero ve ark. (1999) tarafindan bildirilen kriterlere göre TTTS evrelemesi yapıldı.

Bulgular: Belirtilen sürede kliniğimizde 13.368 doğum gerçekleştiği ve bunların 307 'sinin ikiz gebelik olduğu saptandı. İkiz gebeliklerin 196'sını (\%63.8) dikoryonik diamniyotik, 99'unu (\%32.2) monokoryonik diamniyotik ve 12 'sini (\%3.9) ise monokorynik monoamniyotik oluşturmakta idi. Spontan gebelik 256 kadinda (\% 83.4) ve yardımcı üreme teknikleri sonrası gebelik 51 kadında (\%16.6) kaydedildi. Monokoryonik diamniyotik gebelerin 31'i (\%31.3) TTTS ile komplike idi. Yenidoğanlarda sınıflama yapılırken alıcı (polihidroamnioslu fetüsler) Fetüs-A, donör (oligohidroamnioslu fetüs veya stuck-twin görünümlü olan) ise Fetüs-B olarak gruplandırıldı. Postpartum yenidoğanların ağırlı̆̆ı Fetüs-A grubunda $2089 \pm 639$ gram, Fetüs-B grubunda ise $1262 \pm 489$ gram idi $(\mathrm{p}<0.001)$.

Sonuc: Monokoryonik ikiz gebelerin koryonisite ve amniyonisite tayini erken haftalarda yapılmalı ve hastalar antenatal takiplere daha sık çağrılmalıdır. Antenatal takiplerde fetal gelişim farklılıkları, amniyon sıvı uyumsuzluğu veya Doppler profillerinde şüphe durumunda gelişebilecek komplikasyonları yönetebilecek tecrübeye sahip merkezlere yönlendirilmesi önerilmelidir. İkizden ikize transfüzyon sendromu gelişen hastalarda evrelemenin önemi bilinmeli ve erken evre (evre I-II) TTTS'li yenidoğanlarda tedavi sonrası yüz güldürücü sonuçların elde edildiği unutulmamalıdır.

Anahtar sözcükler: Çoğul gebelik, ikiz gebelik, transfüzyon, maternal ve fetal sonuçlar.
Correspondence: Serdar Başaranoğlu, MD. İdil Devlet Hastanesi Kadın Hastalıkları ve Doğum Kliniği, Şırnak, Turkey.

e-mail: drsbasaran@gmail.com

Received: March 7, 2014; Accepted: April 17, 2014
Available online at: www.perinataljournal.com/20140223002 doi:10.2399/prn.14.0223002 QR (Quick Response) Code: 


\section{Introduction}

Multiple pregnancy is the condition of a gravid uterus having two or more fetuses. It constitutes $1-2 \%$ of all pregnancies. The incidence of spontaneous twin pregnancy is reported as 1/90, of triplet pregnancy as $1 / 8000$ and of quadruplet pregnancy as $1 / 700,000 .{ }^{[1]}$ Today, these rates are increased by the use of assisted reproduction techniques. Monozygotic twin pregnancies show up by the division and differentiation of fertilized ovule at different periods during preimplantation phase. ${ }^{[2]}$ Depending on the differences at division time, 29\% of monozygotic twin pregnancies are dichorionic diamniotic (DCDA), 70\% of them are monochorionic diamniotic (MCDA), and 1\% of them are monochorionic monoamniotic (MCMA). ${ }^{[\beta]}$

Twin-to-twin transfusion syndrome (TTTS) is a serious complication seen in $9 \%$ of MCDA twin pregnancies and affecting the pregnancy. ${ }^{[4]}$ Although TTTS is usually observed during second trimester, it can be seen at any period of pregnancy. ${ }^{[5]}$ For establishing the diagnosis, it is significant to detect MCDA pregnancy presence by ultrasonographic examination and to observe oligohydramnios in one of the gestational sacs (if maximum vertical measurement is less than $2 \mathrm{~cm}$ in a single sac) and polyhydramnios in other sac (if maximum vertical measurement is more than $8 \mathrm{~cm}$ in a single sac). ${ }^{[6]}$

Although the pathophysiology of the disease cannot be comprehended well, it is thought that the vascular anastomoses in placental bed have a role. There are three types of vascular anastomoses in monochorionic placentas. Among them, arteriovenous (AV) anastomoses are the most frequent ones and the communication between them is done by arterial nourishment of one of the twins at deep placental capillary levels and venous drainage of the other twin. Unlike AV anastomoses, arterio-arterial (AA) and venovenous (VV) anastomoses are at superficial placenta level and the volume and direction of blood flow between fetuses depend on the pressure difference between the circulations. Anastomosis pattern in twin-to-twin transfusion syndrome is complex and it results with the superiority of net blood flow in receiver fetus from donor depending on the predominance in $\mathrm{AV}$ anastomoses. ${ }^{[7]}$ Serious complications in monochorionic twin pregnancies complicated by twin-to-twin transfusion syndrome such as early birth, intrauterine growth retardation (IUGR), fetal death and neurological deficit increases the importance of prenatal diagnosis, follow-up and treatment. ${ }^{[8]}$
In this study, it was aimed to discuss the results of the newborns and the patients who delivered after the diagnosis of TTTS, follow-up and the treatment at our clinic during perinatal period, together with the current literature data.

Bu çalışmada perinatal dönemde kliniğimizde TTTS tanısı konulup, takip ve tedavilerinden sonra doğumu gerçekleştirilen hasta ve yenidoğanlara ait sonuçların güncel literatür bilgisiyle tartışılması amaçlandı.

\section{Methods}

A total of 330 multiple pregnancies who gave birth at the Obstetrics and Gynecology Clinic of Dicle University between July 2008 and December 2013 were reviewed retrospectively. Before the study, the approval of Ethics Committee of Dicle University was obtained. The data of patients such as age, gravida, parity, obstetric histories, weeks of gestation, chorionicity and amnionicity conditions, treatment methods applied at admission, delivery types, and data of newborns were obtained from hospital archive files. The diagnosis of monochorionic diamniotic pregnancy was established at antenatal follow-ups by observing single placenta and two amniotic sacs and yolk sac at USG before 12 weeks of gestation and single placenta presence at USG, observation of Tsign dividing membrane and determination of same fetal sex after 12 weeks of gestation. Twenty percent weight difference between fetuses, polyhydramnios in receiver fetus, oligohydramnios in donor fetus and/or 'stuck twin' presence depending on the contraction of amniotic membrane were adopted as the criteria for the differential diagnosis of twin-to-twin transfusion syndrome after diagnosing monochorionic pregnancy. In perinatal outcomes, weights, heights, first and 5-minute Apgar scores of newborns, and intrauterine death and early neonatal death were reviewed. When classifying the newborns, receiver fetuses (fetuses with polyhydramnios) were grouped as Fetus-A and donor ones (fetuses with oligohydramnios or those in stuck-twin appearance) were grouped as Fetus-B. Fetal staging was carried out according to the criteria reported by Quintero et al..$^{[9]}$

For statistical analysis, the data were analyzed by Statistical Package for Social Sciences for Windows 15.0 (SPSS Inc., Chicago, IL, USA) and Excel software. The numeric data were checked by Kolmogorov-Smirnov test whether they distributed normal or not, and they were presented as percentage, mean plus/minus and 
standard deviation. Obtained results were considered statistically significant if they were within $95 \%$ confidence interval and $\mathrm{p}<0.005$.

\section{Results}

It was found that 13,368 deliveries were carried out in our clinic and 307 of them were twin pregnancies during the period stated. While $196(63.8 \%)$ of the twin pregnancies were DCDA, $99(32.2 \%)$ of them were MCDA and $12(3.9 \%)$ of them were MCMA. It was confirmed that $256(83.4 \%)$ of the pregnancies were spontaneous and $51(16.6 \%)$ of them were occurred after assisted reproduction techniques. It was observed that $31(31.3 \%)$ of monochorionic diamniotic pregnancies were complicated with TTTS. It was seen that that thirty patients were applied amniodrainage and eight of them had septostomy simultaneously. One of our patients was referred to an external center for photocoagulation treatment by laser at 18 weeks of gestation. It was found out in the USG carried out two weeks after the photocoagulation of the patient referred back to our clinic for the follow-ups that one of the twins was dead.

Age, gravida and parity of the patients and weeks of gestation of twins during delivery are given in Table $\mathbf{1}$. Seven $(22.6 \%)$ of the patients delivered by vaginally and $24(77.4 \%)$ of them by cesarean section. Data of the newborns at postpartum period such as weight, height and first and 5-minute Apgar scores are given in Table 2. The birth weight of newborns in the first group was $2089 \pm 639 \mathrm{~g}$ and it was $1262 \pm 489 \mathrm{~g}$ in the second group; this was found to be statistically significant $(\mathrm{p}<0.001)$. Perinatal mortality rate was $9.7 \%(n=3)$ in Fetus-A group and $25.8 \%(\mathrm{n}=8)$ in Fetus-B group.

\section{Discussion}

Monozygotic multiple pregnancies constitute $1 / 3$ of all twin pregnancies and they occur by the fertilization of a single ovule by a single sperm. Although twin pregnancies are only $1-2 \%$ of all pregnancies, they are responsible for $12.6 \%$ of perinatal mortality. ${ }^{[10]}$ In recent years, the increase in pregnancies at advanced ages and assisted reproduction techniques being common have caused the incidence of multiple pregnancy to increase at a distinct level. It was reported that the incidence of monozygotic twin pregnancies at particularly in vitro fertilization (IVF) cycles increased 2 to 12 times. ${ }^{[11,12]} \mathrm{It}$ was found that $230(83.3 \%)$ of the twin pregnancies in
Table 1. Clinical characteristics of the patients.

\begin{tabular}{|c|c|c|c|c|}
\hline & & $\mathbf{N}$ & Mean \pm SD & Min-Max \\
\hline \multicolumn{2}{|l|}{ Age } & 31 & $28.6 \pm 6.9$ & $14-47$ \\
\hline \multicolumn{2}{|l|}{ Gravida } & 31 & $3.8 \pm 0.6$ & $1-12$ \\
\hline \multicolumn{2}{|l|}{ Parity } & 31 & $2.3 \pm 0.5$ & $0-10$ \\
\hline \multirow{2}{*}{$\begin{array}{l}\text { Weeks of gestation } \\
\text { of the twins }\end{array}$} & Fetus-A & 31 & $32.7 \pm 3.4$ & $21-36$ \\
\hline & Fetus-B & 31 & $27.2 \pm 2.8$ & $18-32$ \\
\hline
\end{tabular}

SD: Standard deviation

Table 2. Weights, heights, and first and 5-minute Apgar scores of the newborns.

\begin{tabular}{lcc} 
& $\begin{array}{c}\text { Fetus-A } \\
\text { (Mean } \pm \text { SD) }\end{array}$ & $\begin{array}{c}\text { Fetus-B } \\
\text { (Mean } \pm \text { SD) }\end{array}$ \\
Weight & $2089.5 \pm 639.5$ & $1261.6 \pm 488.7$ \\
Height & $44.8 \pm 5.3$ & $38.1 \pm 5.6$ \\
1-minute Apgar & $4.8 \pm 2.3$ & $3.4 \pm 2.3$ \\
5-minute Apgar & $6.6 \pm 2.6$ & $4.8 \pm 3.3$ \\
\hline
\end{tabular}

SD: Standard deviation

our study was spontaneous and $36(16.7 \%)$ of them occurred after assisted reproduction techniques. In addition to the increased fetal morbidity in monochorionic diamniotic twin pregnancies, TTTS is another reason which is seen in $9 \%$ of the patients and complicates pregnancy in a serious way. In our study, it was observed that TTTS developed in $31.3 \%$ of MCDA twin pregnancies, and this rate was quite higher than the rates reported in the literature. ${ }^{[4]}$ Our hospital being a tertiary healthcare organization, chosen cases being referred to our clinic, and the less number of experienced physicians working in the field on this subject are the significant reasons. Although twin-to-twin transfusion syndrome is usually seen at second trimester, it may also develop during any period of pregnancy. In our study, it was seen that TTTS developed at the second trimester of $23(74.2 \%)$ patients and this rate was consistent with the literature. In the past years, TTTS diagnosis was being established by $15-20 \%$ difference between birth weights of fetuses or $5 \mathrm{~g} / \mathrm{dl}$ difference between neonatal hemoglobin concentrations. ${ }^{[13,14]}$ Today, the diagnosis is established by the MCDA pregnancy presence found by USG examination (imaging T-sign presence at first trimester is the ideal method) and the presence of poly-oligohydramnios or 'stucktwin' in twins. The diagnoses of the patients in our 
study were established by USG examinations made after taking their detailed obstetric history and also checking newborn weights as additional criteria.

Today, despite the non-presence of a consensus on staging patients with TTTS, the system developed by Quintero et al. in 1999 has been used widely. ${ }^{[9]}$ In the studies carried out at the centers applying fetal therapy, $11-15 \%$ of the patients with TTTS were determined as stage I, $20-40 \%$ of them as stage II, $38-60 \%$ of them stage III, $6-7 \%$ of them as stage IV, and $2 \%$ of them as stage $\mathrm{V}(15,16)$. In these studies, some centers did not take stage I patients with TTTS under evaluation which are at an ignorable level. In our study, $22(71 \%)$ of the patients were in stage I group, $3(9.7 \%)$ in stage II group, $3(9.7 \%)$ in stage III group, $1(3.2 \%)$ in phase IV group, and $2(6.5 \%)$ in stage $\mathrm{V}$ group. We believe that the differences among the rates are caused by the problems during data transfer of the centers included in the studies.

The treatment options in patients developing twinto-twin transfusion syndrome vary from conservative observational approach to invasive approaches such as amnioreduction, septostomy done to membranes, fetoscopic laser photocoagulation and selective feto-reduction. ${ }^{[5]}$ Although laser photocoagulation is considered as an appropriate treatment in advanced stage patients (stage $\geq 3$ ), the management of early stages are controversial. In a study evaluating multi-centered stage I patients, no significant difference in terms of neonatal lifetime was found in the comparison of those undergone laser treatment and those undergone amnioreduction. ${ }^{[17]}$ Although Stirnemann et al. reported in their study that laser photocoagulation application in stage I patients caused higher neonatal lifetime compared amnioreduction (93.1\% vs. $85.7 \%$ ), the study carried out by Wagner and Huber showed that the treatment options had no impact on neonatal lifetime. ${ }^{[18-20]}$ Laser photocoagulation is usually preferred in patients with early onset severe TTTS referred between 16 and 26 weeks of gestation. Eurofetus study group randomized 72 women treated by laser photocoagulation and 70 women treated by amnioreduction, a total of 142 women from 6 countries within 3 years who referred due to severe TTTS development between 15 and 26 weeks of gestation. The survival rate of at least one fetus was found to be significantly higher in the group treated by laser photocoagulation compared to amnioreduction group ( $76 \%$ vs. $56 \%$, $\mathrm{p}=0.009)$. At the same time, mean weeks of gestation during delivery was found to be higher in the group treated by laser photocoagulation (33 weeks-29 weeks, $\mathrm{p}=0.004) .{ }^{[21]}$ Since there was no laser photocoagulation clinic in our hospital, amnioreduction and/or septostomy is applied to the patients who are established early stage diagnosis or symptomatic. Only one of our patients underwent laser photocoagulation at an external center due to her early week of gestation and delivered at 36 weeks of gestation.

It is estimated that the development of twin-to-twin transfusion syndrome is responsible for $17 \%$ of the total perinatal deaths in twin pregnancies and about half of the perinatal deaths of MCDA twins. ${ }^{[2,23]}$ Neonatal survival is directly associated with the stage of the disease. Twin-to-twin transfusion syndrome progresses mostly in a predictable way and the condition of three out of four stage I patients may regress without any treatment. ${ }^{[23-25]}$ However, perinatal death rate in patients with advanced stage (stage $\geq 3$ ) TTTS before 26 weeks of gestation is between $70 \%$ and $100 \% .^{[26,27]}$ In our study, post-partum death was observed in two $(2 / 22)$ stage I newborns and neonatal survival rate was found as $91 \%$. This was similar with the neonatal survival rate in patients who had amnioreduction. It was found that 8 of 12 newborns $(66.7 \%)$ of 6 patients with advanced stage (stage $\geq 3$ ) TTTS were post-partum dead and 4 newborns required intense care follow-up.

\section{Conclusion}

Consequently, chorionicity and amnionicity determination should be carried out at early weeks of gestation of monochorionic twins and the patients should be called for routine antenatal follow-ups more frequently. Analysis of these patients should be carried out by specialists who have detailed USG and Doppler experience and able to manage complications that may develop. During their antenatal follow-ups, they should be recommended to refer to the centers for diagnosis and treatment in case of abnormal or inconsistent amniotic fluid, intrauterine growth retardation or doubt in their Doppler profiles. The importance of staging in women particularly developing TTTS should be acknowledged and it should be remembered that pleasing results can be achieved after the treatment in newborns with early stage TTTS (stage I-II). Treatment methods applied for this condition has still been suboptimal, and we believe that a consensus can be reached for optimal treatment option by carrying out multi-centered studies in Turkey 
and that actual incidence can be determined by carrying out community-based studies instead of hospital-based studies. Also, the impact of the disease on prognosis will be understood better by analyzing newborns with TTTS in further periods.

Conflicts of Interest: No conflicts declared.

\section{References}

1. Kazandı M, Turan V. Çoğul gebelikler ve komplikasyonları. Türk Jinekoloji ve Obstetrik Derneği Dergisi 2011;8:21-4.

2. Pijnenborg JM, Oei SG. The monoamniotic twin: a riskful event. Eur J Obstet Gynecol Reprod Biol 1999;86:51-3.

3. Yıldırım G, Güngördük K, Aslan H, Gül A, Ceylan Y. Monoamniyotik ikiz gebelik: 16 olgunun retrospektif analizi. Turkiye Klinikleri J Gynecol Obst 2008;18:10-6.

4. Lewi L, Gucciardo L, Huber A, Jani J, Van Mieghem T, Doné E, et al. Clinical outcome and placental characteristics of monochorionic diamniotic twin pairs with early- and lateonset discordant growth. Am J Obstet Gynecol 2008;199: 511.e1-7.

5. Mosquera C, Miller RS, Simpson LL. Twin-twin transfusion syndrome. Semin Perinatol 2012;36:182-9.

6. Simpson LL. Twin-twin transfusion syndrome. In: Copel JA, ed. Obstetric imaging. Philadelphia: Elsevier; 2012. p. 173-83.

7. WAPM Consensus Group on Twin-to-Twin Transfusion; Baschat A, Chmait RH, Deprest J, Gratacós E, Hecher K, Kontopoulos E, et al. Twin-to-twin transfusion syndrome (TTTS). J Perinat Med 2011;39:107-12.

8. Lee YM, Wylie BJ, Simpson LL, D'Alton ME. Twin chorionicity and the risk of stillbirth. Obstet Gynecol 2008;111: 301-8.

9. Quintero R, Morales WJ, Allen MH, Bornick PW, Johnson PK, Kruger M. Staging of twin-twin transfusion syndrome. J Perinatol 1999;19; (8 Pt 1):550-5.

10. Powers WF, Kielly JL. The risk confronting twins: a national prespective. Am J Obstet Gynecol 1994;170:456-61.

11. Blickstein I. Estimation of iatrogenic monozygotic twinning rate following assisted reproduction: pitfalls and caveats. Am J Obstet Gynecol 2005;192:365-86.

12. Aston KI, Peterson CM, Carrell DT. Monozygotic twinning associated with assisted reproductive technologies: a review. Reproduction 2008;172:377-86.

13. Rausen AR, Seki M, Strauss L. Twin transfusion syndrome. A review of 19 cases studied at one institution. J Pediatr 1965;66:613-28.

14. Wenstrom KD, Tessen JA, Zlatnik FJ, Sipes SL. Frequency, distribution, and theoretical mechanisms of hematologic and weight discordance in monochorionic twins. Obstet Gynecol 1992;80:257-61.

15. Gandhi M, Papanna R, Teach M, Johnson A, Moise KJ Jr. Suspected twin-twin transfusion syndrome: how often is the diagnosis correct and referral timely? J Ultrasound Med 2012;31:941-5.

16. Rossi AC, D'Addario V. The efficacy of Quintero staging system to assess severity of twin-twin transfusion syndrome treated with laser therapy: a systematic review with metaanalysis. Am J Perinatol 2009;26:537-44.

17. Quintero RA, Dickinson JE, Morales WJ, Bornick PW, Bermúdez C, Cincotta R, et al. Stage-based treatment of twintwin transfusion syndrome. Am J Obstet Gynecol 2003;188: 1333-40.

18. Stirnemann JJ, Mougeot M, Proulx F, Nasr B, Essaoui M, Fouron JC, et al. Profiling fetal cardiac function in twin-twin transfusion syndrome. Ultrasound Obstet Gynecol 2010;35: 19-27.

19. Wagner MM, Lopriore E, Klumper FJ, Oepkes D, Vandenbussche FP, Middeldorp JM. Short and long-term outcome in stage 1 twin-to-twin transfusion syndrome treated with laser surgery compared with conservative management. Am J Obstet Gynecol 2009;201:286, e1-6.

20. Huber A, Diehl W, Bregenzer T, Hackelöer BJ, Hecher K. Stage-related outcome in twintwin transfusion syndrome treated by fetoscopic laser coagulation. Obstet Gynecol 2006; 108:333-7.

21. Deprest J, Boulvain M, Paupe A, Winer N, Ville Y. Endoscopic laser surgery versus serial amnioreduction for severe twin-to-twin transfusion syndrome. N Engl J Med 2004;351:136-44.

22. Lewi L, Jani J, Blickstein I, Huber A, Gucciardo L, Van Mieghem T, et al. The outcome of monochorionic diamniotic twin gestations in the era of invasive fetal therapy: a prospective cohort study. Am J Obstet Gynecol 2008;199: 514.e1-8.

23. Steinberg LH, Hurley VA, Desmedt E, Beischer NA. Acute polyhydramnios in twin pregnancies. Aust $\mathrm{N} \mathrm{Z} \mathrm{J} \mathrm{Obstet}$ Gynaecol 1990;30:196-200.

24. Bebbington MW, Tiblad E, Huesler-Charles M, Wilson RD, Mann SE, Johnson MP. Outcomes in a cohort of patients with stage I twinto- twin transfusion syndrome. Ultrasound Obstet Gynecol 2010;36:48-51.

25. Rossi C, D'Addario V. Survival outcomes of twin-twin transfusion syndrome in stage I: a systematic review of the literature. Am J Perinatol 2013;30:5-10.

26. Berghella V, Kaufmann M. Natural history of twin-twin transfusion syndrome. J Reprod Med 2001;46:480-4.

27. Gul A, Aslan H, Polat I, Cebeci A, Bulut H, Sahin O, et al. Natural history of 11 cases of twin-twin transfusion syndrome without intervention. Twin Res 2003;6:263-6. 